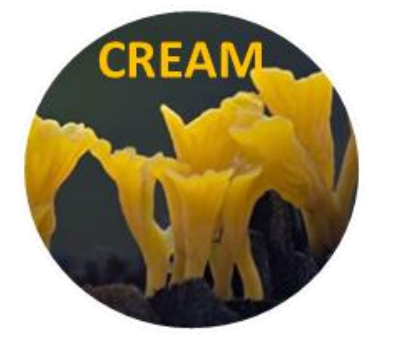

Current Research in Environmental \& Applied Mycology 5 (3): 277-284 (2015) ISSN 2229-2225

www.creamjournal.org

Article

CREAM

Copyright $(2015$

Doi 10.5943/cream/5/3/11

Online Edition

\title{
Antifungal activity of fungicides and plant extracts against yellow sigatoka disease causing Mycosphaerella musicola
}

\author{
Aman M and Rai VR* \\ Department of Studies in Microbiology, University of Mysore, Manasagangotri, Mysore - 570006, INDIA
}

Aman M, Rai VR 2015 - Antifungal activity of fungicides and plant extracts against yellow sigatoka disease causing Mycosphaerella musicola. Current Research in Environmental \& Applied Mycology 5(3), 277-284, Doi 10.5943/cream/5/3/11

\begin{abstract}
Mycosphaerella musicola causes yellow sigatoka disease in banana plantations, and affects overall yield and quality of the fruit. Synthetic fungicides are used to control disease. An integrated approach by using plant based extracts and synthetic fungicides can control the disease efficiently by reducing the usage of fungicides. In vitro studies were carried out to test methanolic extracts of ten plants belonging to seven different families having previous reports on antimicrobial activity against Mycosphaerella musicola, methanolic extracts of two plants showed significant antifungal activity as well as significant inhibition of spore germination in spore germination inhibition assay. All eight fungicides exhibited inhibitory action on M. musicola in poison food technique, where as MIC range of each fungicide varied significantly. The results revealed that integrated disease management by using efficient plant extracts and effective fungicides can control the disease and the pathogen in fields efficiently.
\end{abstract}

Keywords - Antifungal activity - fungicides - Mycosphaerella musicola - plant extracts - spore germination inhibition assay.

\section{Introduction}

Sigatoka disease in banana plantation is one of the serious disease after panama wilt, considered as a potential threat to the banana production globally (Arzanlou et al. 2008) Mycosphaerella sp, causes sigatoka disease (Irish et al. 2013), as disease progress to advanced stages large photosynthetic area of leaf will be destructed, resulting in premature falling of leaves and premature mature ripening of fruits (Ramsey et al. 1990). Mycosphaerella genus contains several species, known to cause foliar spots on the banana plantain (Henderson et al. 2006). Mycosphaerella fijiensis Morelet causes black sigatoka disease, Mycosphaerella musicola Leach, causes yellow sigatoka and Mycosphaerella emusae causes Eumusae leaf spots of banana (Ramsey et al. 1990, Jones 1999). Sigatoka disease is wide spread in all major banana growing areas, specifically in South East Asia, Pacific, Latin America and Africa (Jones 1999). Asian countries including West Malaysia, Thailand, Vietnam, Southern India and Sri Lanka the disease is found serendipitously (Carlier et al. 2000, Crous \& Mourichon 2002). In India Sigatoka disease have been reported from several states such as Tamil Nadu, Kerala, Karnataka, Andhra Pradesh, Maharashtra, Gujarat, West Bengal and North eastern hilly states of India (Selvarajan et al. 2001). 
Management of Sigatoka disease is usually done by the application of fungicides in commercial plantations (Herrmanto et al. 2010). Due to the increased usage of chemical fungicides, fungicides consume $25 \%$ of overall banana production cost (Ploetz 2000). Annually 20-25 cycles of fungicide application is done for the disease management (Peterson et al. 2002). Due to the excess usage of the fungicides, there are reports indicating the fungicide resistance for contact fungicides such as mancozeb, chlorothalonil from the major banana growing areas such as Belize, Cameroon, Central America and Costa Rica (Bellaire et al. 2009, Smith 1988, Churchill 2011). Due to the emergence of fungicide resistance has led to the application of fungicides up to 40-45cycles annually (Bellaire et al. 2009). The long term usage of the fungicides also has adverse impact on environment, contaminating the food sources and water bodies (Ndoumbe-Nkeng \& Sache 2003). Several disease management strategies such as phyto-sanitation, application of bio control agents, disease forecasting in the commercial banana growing areas have planned and executed for the reduction of fungicide usage (Ngongo 2002). Conversely sigatoka disease of banana remains as a major constrain in the global banana production (Raut \& Ranade 2004). Controlling the spread of Sigatoka disease can also achieved by screening of Mycosphaerella isolates for the fungicide resistance and recommending the banana growing farmers, about the fungicides to which the pathogen is highly susceptible (Fullerton \& Olsen 1991, Mouliom-Pefoura et al. 1996). Current work focuses on the in-vitro screening of Mycosphaerella musicola against the different systemic and contact fungicides and plant extracts

\section{Materials \& Methods}

\section{Collection and preparation of plant material and fungicides for in vitro evaluation}

Fresh disease free foliar and bark samples were collected from surrounding hilly areas of Sakleshpur and Subramanya, Karnataka state, India, in the month of March 2014 (Table 1). Leaves and bark samples were washed thoroughly in running tap water to remove dust and shade dried. Leaf samples were blended in Waring blender (Waring International, New Hartford, CT, USA) for 5 minutes to form coarse powder. $20 \mathrm{~g}$ of powder was extracted with $100 \mathrm{ml}$ of Methanol for 8 hours, centrifuged at $10,000 \mathrm{x} \mathrm{g}$ for $20 \mathrm{~min}$ and the supernatant was flash evaporated using rotary flash evaporator (Buchi $\mathrm{R}-3$ rotavapor, USA). The extracts were preserved at $4{ }^{\circ} \mathrm{C}$ for further usage. Commonly used commercial grade contact and systemic fungicides were procured from the local agro-chemical vendors were used in this study (Table 2).

Table 1 List of medicinal plants and their parts used in the study.

\begin{tabular}{cllll}
\hline Sl. No. & \multicolumn{1}{c}{ Name of the plant } & Code & Family & Parts used \\
\hline 1 & Aristolochiatagala Cham & AT & Aristolochiaceae & Leaves \\
2 & Casearia tomentosa Roxb. & CT & Salicaceae & Leaves \\
3 & Garcinia cambogia Gaerth & GC & Clusiaceae & Leaves \\
4 & Garcinia xanthochymus Hook.f. & GX & Clusiaceae & Leaves \\
5 & Salacia fruticosa Wall. & SF & Hippocrateaceae & Leaves \\
6 & Terminalia belerica Roxb. & TB & Combretaceae & Leaves \\
7 & Terminalia chebula Retz & TC & Combretaceae & Leaves \\
8 & Terminalia paniculata Roth & TP & Combretaceae & Leaves \\
9 & Orthosiphon diffusus Benth. & OD & Lamiaceae & Leaves \\
10 & Redermachera xylocarpa Roxb & RX & Bignoniaceae & Bark \\
\hline
\end{tabular}

Table 2 List of commercial available fungicides used in the study.

\begin{tabular}{clllc}
\hline Sl. No. & \multicolumn{1}{c}{ Name } & \multicolumn{1}{c}{ Active ingredients } & Mode of action & Code \\
\hline 1 & Baylethon & Triadimefon 125g/1000 ml & Systemic & F1 \\
2 & Taqat & Captan 70\% + Hexaconazole 5\% & Contact + Systemic & F2 \\
3 & Ridomil MZ 72 & Metalaxyl 8\% + Mancozeb 64\% & Systemic & F3 \\
4 & Contaff plus & Hexaconazole 5\% & Systemic & F4 \\
5 & Lurit & Dimethomorph 50\% & Systemic & F5 \\
6 & Mirador & Azoxystrobin 23\% & Systemic & F6 \\
7 & Sectin & Fenamidone 10\% + Mancozeb 50\% & F7 \\
8 & Bavstin & Carbendazim 50\% & Systemic & F8 \\
\hline
\end{tabular}




\section{Isolation and maintenance of fungal culture}

Fungal isolate Mycosphaerella musicola MM1 (GenBank accession No.KM369832) was selected for the current study (Aman \& Rai 2015). The fungal culture was maintained by repeated sub culturing on to potato dextrose agar (PDA) in monthly basis.

\section{Screening of plant extracts against Mycosphaerella musicola}

Methanolic extracts $(25,20,15,10,5 \%)$ of all the plants were amended with MEPDA (Malt extract potato dextrose agar media) prior to solidification of medium. $5 \mathrm{~mm}$ mycelial plugs of $M$. musicola was inoculated on treated media and three replicates were maintained for each treatment (Kumar \& Prasad 1992). The percent inhibition of mycelial growth was calculated using the formula: Percent inhibition $=\mathrm{C}-\mathrm{T} / \mathrm{C}$ X 100 where $\mathrm{C}=$ Fungal growth in control and $\mathrm{T}=$ Fungal growth in treatment.

\section{Spore germination inhibition assay}

Induction of vegetative spores in $M$. musicola was done by inoculating fungus on $\mathrm{V}-8$ agar media (Himedia, Mumbai, India), and incubated for 5 days at $28{ }^{\circ} \mathrm{C} .50 \mu \mathrm{L}$ of plant extracts $(1 \mathrm{mg} / \mathrm{ml})$ exhibiting antifungal activity were treated with spore suspension $\left(10^{8}\right.$ spores/ ml $)$ and incubated for 24 hours at $28{ }^{\circ} \mathrm{C}$. Enumeration of germinated and non germinated spores was done by hemocytometer under $40 \mathrm{X}$ magnification (Begum et al. 2010)

\section{Screening of fungicides against $M$. musicola}

Screening of fungicides against $M$. musicola was done at their recommended dosage $(2 \mathrm{~g} / \mathrm{L})$ for antifungal activity by poisoned food technique as described above.

\section{Minimum inhibitory concentration (MIC)}

All 8 fungicides were used to determine MIC. Different concentrations of each fungicide $(1,3$, $7,10,30,60,120,250,500,1000 \mu \mathrm{g} / \mathrm{ml})$ were prepared separately by dissolving their requisite amount in $950 \mu 1$ of distilled water. $50 \mu 1$ of spore suspension was inoculated and incubated for 7 days. Mycelial biomass was separated from all treated aliquots dried and weighed to determine MIC. A triplicate of each concentration was done.

\section{Statistical analysis}

Anti fungal activity of plant extracts and fungicides against $M$. musicola was analyzed using mean of 3 replicates \pm standard deviation (SD) and One way Anova followed by Tukey's test. All statistical analysis was performed using Graph Pad Prism software.

\section{Results}

\section{Antifungal activity of plant extracts against $M$. musicola}

Result revealed that among 10 plants screened for antifungal activity, methanolic extracts from leaves of RX and OD showed high antifungal activity. Antifungal activity of all plants reduced with decrease in extract concentration. Inhibitory percentage of RX and OD was maximum (35.2 \pm 0.4 and $34 \pm 0.5$ ) at $5 \%$ of plant extracts. AT, GC and GX showed moderate antifungal activity with percentage of inhibition ranging from $10.3 \pm 0,8.5 \pm 1.6$ and $9.0 \pm 0$ respectively whereas methanolic extracts from the leaves of SF,CT, TB, TC and TP did not showed any inhibitory action against M. musicola at $5 \%$ concentration of plant extracts (Table 3).

\section{Spore germination inhibition assay}

Extracts $(1 \mathrm{mg} / \mathrm{ml})$ from RX and OD exhibited highest inhibitory effect on spore germination of M. musicola. However leaf extract of GC had sporicidal activity, inhibiting spore germination partially. Extracts from the leaves of CT, TB, TC and TP did not show any spore germination inhibitory activity (Fig. 1). 


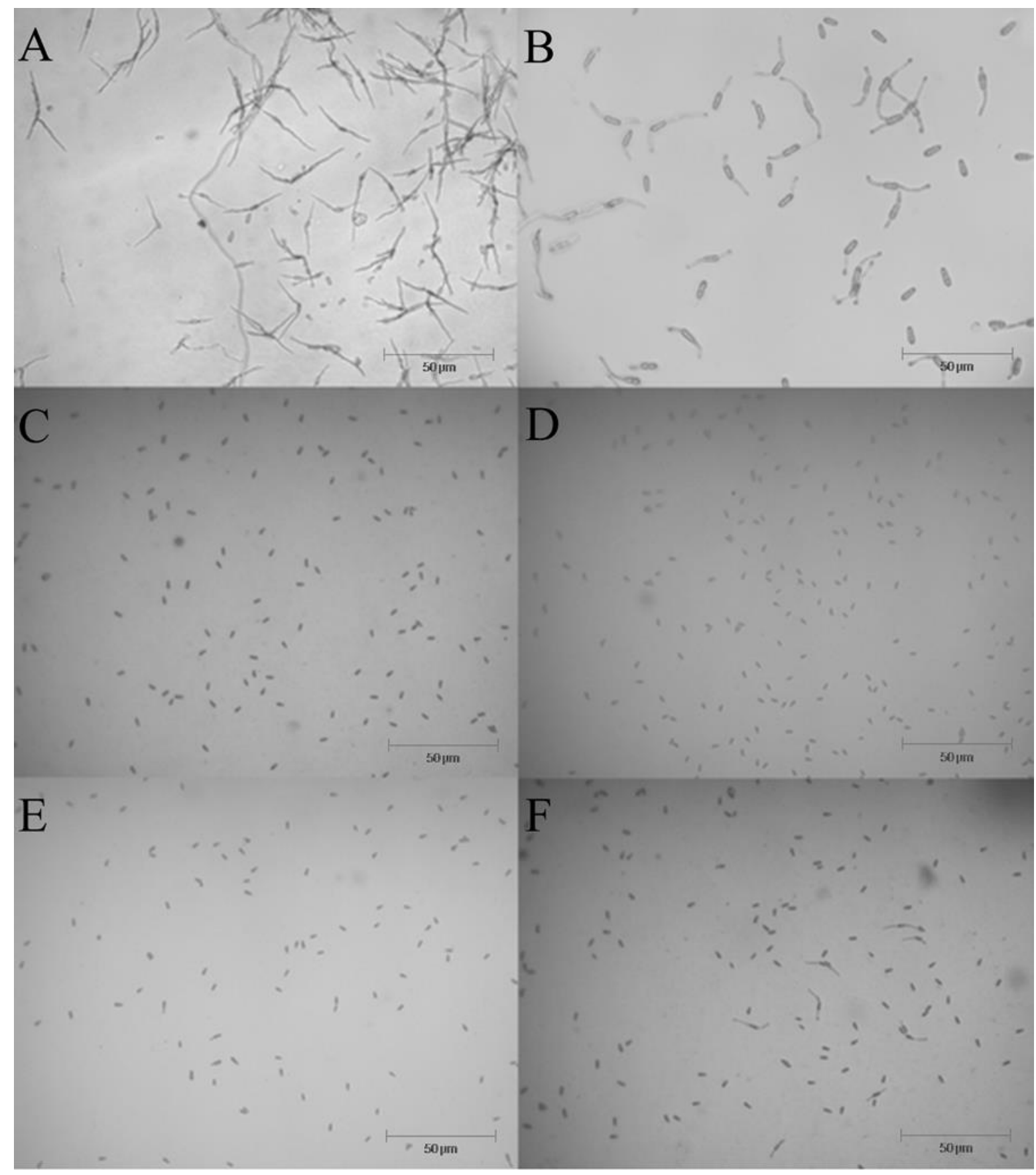

Fig. 1 - Inhibitory effect of methanolic plant extracts on germination and viability of $M$. musicola ascospores. Untreated ascospores (A, B) showing extensive spore germination with least spore mortality. Carbendazim treated ascospores $(1 \mathrm{mg} / \mathrm{ml})(\mathrm{C})$ showing ungerminated conidia. Methanolic bark extracts of $R$. xylocarpa Roxb treated ascospores $(1 \mathrm{mg} / \mathrm{ml}$ ) (D) showing ungerminated conidia with no viable spores. Methanolic leaf extract of $O$. diffusus Benth inhibited spore germination effectively (E), small proportions of viable ascospores were visible. Leaf extracts from G.cambogia Gaertn reduced conidial germination and incidence of viable spores was increased marginally $(F)$.

\section{Effect of fungicides on the growth of $M$. musicola}

Poisoned food technique was conducted to observe the effect of eight systemic and contact on the growth of $M$. musicola. All fungicides inhibited the fungal growth completely at the concentration recommended by the manufacturers; however MIC range of all fungicides varied significantly (Table 4), F2 was more efficient with an MIC range of $7.8 \mu \mathrm{g} / \mathrm{ml}$, followed by F4, F7 and F8 had MIC range of $31.2 \mu \mathrm{g} / \mathrm{ml}$, were as F5 and F6 exhibited least MIC range of $500 \mu \mathrm{g} / \mathrm{ml}$. 
Table 3 Inhibitory activity of Methanolic plant extracts against M. musicola at different concentrations by poison food technique.

\begin{tabular}{|c|c|c|c|c|c|c|c|c|c|c|c|}
\hline \multirow{2}{*}{$\begin{array}{l}\text { Sl. } \\
\text { No }\end{array}$} & \multirow{2}{*}{$\begin{array}{c}\text { Concentration } \\
\text { of extract }\end{array}$} & \multicolumn{10}{|c|}{ Percentage of Inhibition* } \\
\hline & & AT & CT & GC & GX & SF & TB & TC & $\mathbf{T P}$ & OD & RX \\
\hline 1 & $25 \%$ & $50.3 \pm 2.1^{\mathrm{a}}$ & $31.6 \pm 1.2$ & $68 \pm 1.6^{\mathrm{b}}$ & $40 \pm 1.7$ & $32.1 \pm 1$ & $35.8 \pm 0.8$ & $34.5 \pm 1.2$ & $25.4 \pm 1.2$ & $67.2 \pm 0.6^{b}$ & $73.4 \pm 0.7^{b}$ \\
\hline 2 & $20 \%$ & $35.2 \pm 2.7^{\mathrm{a}}$ & $14.5 \pm 1.1$ & $59.4 \pm 0.7^{\mathrm{b}}$ & $33.4 \pm 0.6$ & $20.7 \pm 0.8$ & $24.3 \pm 0.6$ & $24.3 \pm 0.2$ & $21.2 \pm 0.9$ & $64.3 \pm 0.7^{\mathrm{b}}$ & $60.7 \pm 0.3^{b}$ \\
\hline 3 & $15 \%$ & $28 \pm 0.3^{\mathrm{a}}$ & $12.7 \pm 1.7$ & $42.5 \pm 1.7^{\mathrm{b}}$ & $24.9 \pm 1$ & $14.5 \pm 1.1$ & $11.6 \pm 0.5$ & $15.2 \pm 0.6$ & $8.5 \pm 0.2$ & $52.7 \pm 0.3^{b}$ & $52.7 \pm 0.8^{\mathrm{b}}$ \\
\hline 4 & $10 \%$ & $21.2 \pm 0.9^{\mathrm{a}}$ & $12.1 \pm 0.7$ & $26.7 \pm 1.1^{\mathrm{b}}$ & $19.4 \pm 0.9$ & $4.9 \pm 0.3$ & $4.3 \pm 0.4$ & $9.0 \pm 0$ & $8.5 \pm 0.6$ & $40.7 \pm 0.2^{b}$ & $42.5 \pm 0.3^{b}$ \\
\hline 5 & $5 \%$ & $10.3 \pm 0^{\mathrm{a}}$ & $7.2 \pm 0.2$ & $8.5 \pm 1.6^{\mathrm{b}}$ & $9.0 \pm 0$ & $4.9 \pm 0.2$ & $6.7 \pm 0.2$ & $5.4 \pm 0.1$ & $4.9 \pm 0.5$ & $34 \pm 0.5^{b}$ & $35.2 \pm 0.4^{\mathrm{b}}$ \\
\hline
\end{tabular}

*Values are mean $\pm \mathrm{SD}$ of three parallel measurements. The results were analyzed by One Way Anova followed by Tukey's test ${ }^{\mathrm{a}} \mathrm{P}<0.05,{ }^{\mathrm{b}} \mathrm{P}<0.01$

Table 4 MIC values of different fungicides at varied concentrations against M. musicola.

\begin{tabular}{|c|c|c|c|c|c|c|c|c|c|}
\hline \multirow{2}{*}{$\begin{array}{l}\text { Sl. } \\
\text { No }\end{array}$} & \multirow{2}{*}{$\begin{array}{l}\text { Concentration } \\
\text { In } \mu \mathrm{g} / \mathrm{ml}\end{array}$} & \multicolumn{8}{|c|}{ Dried mycelial biomass in mg } \\
\hline & & F1 $^{\mathrm{a}}$ & $\mathbf{F 2}^{\mathrm{c}}$ & $\mathbf{F 3}^{\mathrm{a}}$ & $\mathbf{F 4}^{\mathrm{c}}$ & $\mathbf{F 5}^{\mathrm{b}}$ & F6 $^{\mathrm{b}}$ & $\mathrm{F7}^{\mathrm{c}}$ & $\mathbf{F 8}^{\mathrm{c}}$ \\
\hline 1 & 1000 & 0 & 0 & 0 & 0 & 0 & 0 & 0 & 0 \\
\hline 2 & 500 & 0 & 0 & 0 & 0 & $3.2 \pm 0.2$ & $1.5 \pm 0.2$ & 0 & 0 \\
\hline 3 & 250 & 0 & 0 & $0.9 \pm 0.1$ & 0 & $4.4 \pm 0.1$ & $2.1 \pm 0.2$ & 0 & 0 \\
\hline 4 & 125 & $6.1 \pm 0.4$ & 0 & $5.4 \pm 0.2$ & 0 & $5.3 \pm 0.1$ & $3.1 \pm 0.4$ & 0 & 0 \\
\hline 5 & 62.5 & $6.2 \pm 0.4$ & 0 & $7.1 \pm 0.5$ & 0 & $5.8 \pm 0.1$ & $4.9 \pm 0.1$ & 0 & 0 \\
\hline 6 & 31.2 & $7.5 \pm 0.3$ & 0 & $8.7 \pm 0.2$ & $0.9 \pm 0.1$ & $6 \pm 0.2$ & $6.7 \pm 0.1$ & $0.6 \pm 0.2$ & $1.3 \pm 0.1$ \\
\hline 7 & 15.6 & $8.2 \pm 0.4$ & 0 & $9.6 \pm 0.6$ & $1.1 \pm 0.2$ & $6.3 \pm 0.3$ & $7.2 \pm 0.1$ & $4.8 \pm 0.1$ & $1.6 \pm 0.3$ \\
\hline 8 & 7.8 & $10.2 \pm 0.6$ & $0.8 \pm 0.1$ & $9.8 \pm 0.1$ & $2.1 \pm 0.5$ & $6.6 \pm 0.3$ & $7.4 \pm 0.1$ & $6 \pm 0.3$ & $1.6 \pm 0.1$ \\
\hline 9 & 3.9 & $10.3 \pm 0.2$ & $1.7 \pm 0.2$ & $10.2 \pm 0.3$ & $4.8 \pm 0.2$ & $9.2 \pm 0.3$ & $8.3 \pm 0.3$ & $7.6 \pm 0.2$ & $2.3 \pm 0.1$ \\
\hline 10 & 1.9 & $10.3 \pm 0.3$ & $2.2 \pm 0.5$ & $10.9 \pm 0.1$ & $8 \pm 0.1$ & $9.7 \pm 0.1$ & $10.0 \pm 0.1$ & $8.8 \pm 0.5$ & $5.1 \pm 0.3$ \\
\hline
\end{tabular}

*Values are mean $\pm \mathrm{SD}$ of three parallel measurements. The results were analyzed by One Way Anova followed by Tukey's test ${ }^{\mathrm{a}} \mathrm{P}<0.05,{ }^{\mathrm{b}} \mathrm{P}<0.01$, ${ }^{\mathrm{c}} \mathrm{P}<0.001$ 


\section{Discussion}

Methanolic extracts from $O$. diffusus Benth (Leaves) and $R$. xylocarpa Roxb (Bark) completely inhibited the growth of $M$. musicola (Poison food technique) and maximum inhibition of germinating spores was observed (spore germination inhibition assay). Current work is first to report on antifungal activity of methanolic leaf extract from $O$. diffuses and $R$. xylocarpa Roxb (Bark) against $M$. musicola. Large number of evidence indicates the folk medicinal importance of G. cambogia Gaertn in complimentary and alternate systems used to treat various human diseases (Shivakumar et al. 2013). Methanolic crude extracts from G. atroviridis leaves, fruits, roots, stem and trunk bark exhibited antimicrobial, cytotoxic, antitumour promoting and anti oxidant activities (Mackeen et al. 2000). Fruit extracts from $G$. atroviridis exhibited significant antifungal activity against Cladosporium herbarum (Mackeen et al. 2000). However in current study methanolic extracts from G. cambogia Gaertn inhibited ascospore germination efficiently but failed to exhibit any antifungal activity on actively growing fungal colonies. $O$. diffusus Benth plant paste is used to cure skin infections in folk medicine (Murugesan et al. 2011). Studies on the extracts and oil from O. diffusus Benth showed significant cytotoxicity and hepato-protective nature (Ghaffari et al. 2013, Sadashiva et al. 2013). Limited work has been done on ecofriendly management of fungal diseases in agricultural crops using extracts of $O$. diffusus Benth. However anti microbial studies using ethanolic extracts of O.stamineus Benth showed significant anti bacterial and anti fungal activity (Neharkar \& Laware 2013). Secondary metabolite profiling from different parts of $R$. xylocarpa Roxb conducted by Ekade \& Manik (2014) indicated that all parts of plant are rich in steroidal compounds. Anti microbial study conducted using flower extracts of $R$. xylocarpa Roxb against B. subtilis and E. coli showed strong antibacterial property (Sukumar \& Anandi 2014). Even though $R$. xylocarpa Roxb having high folk medicinal value, based on literature, limited work has been done on antifungal aspects against fungal plant pathogens. Further investigation on isolation and characterization of active molecules responsible for antifungal activity from $R$. xylocarpa Roxb and $O$. diffusus Benth is in progress.

In vitro screening of fungicides for their efficacy against $M$. musicola showed that even though all fungicides inhibited the growth of the pathogen, MIC range varied contrastingly among the fungicides. F2 (Taqat) a mixture of contact and systemic fungicide was more effective against $M$. musicola, with an MIC range of $7.8 \mu \mathrm{g} / \mathrm{ml}$. Present work suggested that extracts from $O$. diffusus Benth, G. cambogia Gaertn and $R$. xylocarpa Roxb can be used in ecofriendly management of sigatoka disease in banana plantations. In commercial banana plantations application of F2 can reduce the number of fungicides spraying cycles. Reduction in fungicide spraying cycles can reduce overall consumption of fungicides for disease management. Combination of plant extracts $(O$. diffusus Benth, $G$. cambogia Gaerth and $R$. xylocarpa Roxb) with $\mathrm{F} 2$ will be more effective in integrated disease management strategy.

\section{Acknowledgement}

The authors are thankful to University of Mysore and University Grant Commission, New Delhi for providing UGC-NONNET fellowship for the first author. We thank to Dr. Sharanappa P, Taxonomist, Department of Studies in Bioscience, University of Mysore, for identifying medicinal plants.

\section{References}

Aman M, Rai VR. 2015 - Potent toxigenic effect of Mycosphaerella musicola on locally growing banana varieties. Phytoparasitica 43, 295-301, DOI 10.1007/s12600-015-0456-3.

Arzanlou M, Groenewald JZ, Fullerton RA, Abeln ECA, Carlier J, Zapater MF, Buddenhagen IW, Viljoen A, Crous PW. 2008 - Multiple gene genealogies and phenotypic characters differentiate several novel species of Mycosphaerella and related anamorphs on banana. Persoonia 20, 1937. 
Begum F, Mahal F, Alam S. 2010 - Inhibition of spore germination and mycelial growth of three fruit rot pathogens using some chemical fungicides and botanical extracts. Journal of life and Earth Science 5, 23-27.

Bellaire LL, Ngando JE, Abadie C, Chabrier C, Blanco R, Lescot T, Carlier J, Cote F. 2009 - Is chemical control of Mycosphaerella foliar diseases of banana sustainable?. In: Acta Horticulturae. Proceedings of the International Symposium on Recent Advances in Banana Crop Protection for Sustainable Production and Improved Livelihoods, White River, South Africa, pp 161-170.

Carlier J, Foure E, Gauhl F, Jones DR, Lepoivre P, Mourichon X, Pasberg-Gahul C, Romero RA. 2000 - Black leaf streak. In: Diseases of Banana (eds DR Jones, Abaca, Enset). CAB International, Wallingford, United Kingdom, pp 37-79.

Churchill A. 2011 - Mycosphaerella fijiensis, the black leaf streak pathogen of banana progress towards understanding pathogen biology and detection, disease development, and the challenges of control. Molecular Plant Pathology 12, 307-328.

Crous PW, Mourichon X. 2002 - Mycosphaerella eumusae and its anamorph Pseudocercospora eumusae spp: causal agent of emusae leaf spot disease of banana. Sydowia 54, 35-43.

Ekade PP, Manik SR. 2014 - Investigations on secondary metabolites in different parts of Radermachera xylocarpa Using GC-MS. Journal of Pharmacognosy and Phytochemistry 2 (6), $39-47$.

Fullerton RA, Olsen TL. 1991 - Pathogenic variability in Mycospharella fijiensis Morelet. In: Banana diseases in Asia and the Pacific (eds RV Valmayor, BE Umali, CP Bojesano). Proceedings of a regional technical meeting on Diseases Affecting Banana and Plantain in Asia and the Pacific, INIBAP, Brisbane, Montpellier, France. pp 105-114.

Ghaffari HM, Venkataramana SC, Nayaka BJ, Ghassam N, Angaswamy S, Shekar KK, Sampath Kumar, Prakash HS. 2013 - Hepatoprotective action of Orthosiphon diffusus (Benth.) methanol active fraction through antioxidant mechanisms: an in vivo and in vitro evaluation. Journal of Ethno Pharmacology 149(3), 737-44.

Henderson J, Pattemore JA, Porchun SC, Hayden HL, VanBrunschot S, Grice KRE, Peterson RA Thomas-Hall SR, Aitken EAB. 2006 - Black Sigatoka disease: new technologies to strengthen eradication strategies in Australia. Australasian Journal of Plant Pathology 35, 181-193.

Herrmanto C, Opina OS, Natural MP. 2010 - Assessment of fungicide resistance of a population of Mycosphaerella Spp. On Senorita Banana variety (Sucrier group). Tree and Forestry Science and Biotechnology 4, 85-90.

Irish BM, Goenaga R, Rios C, Chavarria-Carvaja J, Ploetz R. 2013 - Evaluation of banana hybrids for tolerance to black leaf streak (Mycosphaerella fijiensis Morelet) in Puerto Rico. Crop Protection 54, 229-238.

Jones DR. 2000 - Diseases of Banana. In: Abacá and Enset. (eds DR Jones). CABI Publishing, Wallingford, United Kingdom. pp 544.

Kumar S, Prasad G. 1992 - Efficacy of medicinal plant (Andrographis peniculata) extract on aflatoxin production and growth of Aspergillus flavus. Letters in Applied Microbiology 15, 131-132.

Mackeen MM, Ali AM, Lajis NH, Kawazu K, Hassan Z, Amran M, Habsah M, Mooi LY, Mohamed SM. 2000 - Antimicrobial, antioxidant, anti-tumour promoting and cytotoxic activities of different plant part extracts of Garcinia atroviridis griff. exT. anders. Journal of Ethnopharmacology 72(3), 395-402.

Mouliom-Pefoura A, Lassoudiere A, Foko J, Fontem DA. 1996 - Comparison of development of Mycosphaerella fijiensis and Mycosphaerella musicola on banana and plantain in the various ecological zones of Cameroon. Plant Disease 80, 950-954.

Murugesan P, Raja G, Marx SK, Selvam BP. 2011 - Ethnobotanical study of medicinal plants used by villagers in Kolli hills of Namakkal district of Tamil Nadu, India. International Journal of Pharmaceutical Sciences Review and Research 10 (1), 170-173.

Ndoumbe-Nkeng M, Sache I. 2003 - Luttecontre la pourriturebrune des cabosses du cacaoyer au Cameroun. Phytoma, 562, 10-12. 
Neharkar V, Laware S. 2013 - Antibacterial and Antifungal activity of Hydro-Alcoholic extract of Orthosiphon stamineus benth. International Journal of Pharmaceutical and Chemical Science 2(2), 713-715.

Ngongo PMK. 2002 - Integrated crop management strategies for plantain production and control of black leaf streak (black Sigatoka) disease in the Democratic Republic of Congo, Disease control of black Sigatoka. Info Musa, 11 (1), 3-6.

Peterson RK, Grice, De La Rue S. 2002 - Management of Mycosphaerella leaf spot diseases in Australia. In: Mycosphaerella leaf spot diseases of bananas: present status and outlook (eds LP Jacome, D Lepoivre, R Marin, R Ortiz, Romero, JV Escalant). Proceedings of the $2^{\text {nd }}$ international workshop on Mycosphaerella leaf spot diseases, San Jose, Costa Rica, pp 271276.

Ploetz R. 2000 - Black Sigatoka. Pesticide Outlook 11, 19-23.

Ramsey MD, Daniells JW, Anderson VJ. 1990 - Effects of sigatoka leaf spot (Mycosphaerella musicola Leach) on fruit yield, field ripening and green life of bananas in North Queensland. Scientia Horticulturae 41, 305-313.

Raut SP, Ranade S. 2004 - Diseases of banana and their management. In: Diseases of fruits and vegetables (eds Naqvi, S. A. M. H). Kluwer Academic Publishers, Netherlands, pp 37-52.

Sadashiva CT, Sharanappa P, Naidoo Y, Sulaimon CT, Indira B. 2013 - Chemical composition of essential oil from Orthosiphon diffuses Benth. Journal of Medicinal Plants Research 7(4), 170 172.

Selvarajan RS, Uma, Sathiamoorthy S. 2001 - Etiology and survey of banana leaf spot diseases in India. Advancing banana and plantain R \& D in Asia and the Pacific 10, 94-102.

Shivakumar S, Sandhiya S, Subhasree N, Agrawal A, Dubey GP. 2013 - In vitro assessment of antibacterial and antioxidant activities of fruit rind extracts of Garcinia cambogia. International Journal of Pharmacy and Pharmaceutical Sciences 5(2), 254-257.

Smith CM. 1988 - History of benzimidazole use and resistance. In: Fungicide resistance in North America (eds CJ Delp). APS press, St. Paul, Minnesota, pp 23-24.

Sukumar D, Anandhi B. 2014 - Antibacterial Studies on the Isolates of Radermachera xylocarpa. International Journal of Scientific Research 3(4), 63-65. 